\title{
Jumlah dan Jenis Fitoplankton Di Muara Sungai Banjir Kanal Barat Semarang
}

\author{
Anantya Setya Perdana*, Raden Ario, Hadi Endrawati \\ Departemen IImu Kelautan, Fakultas Perikanan dan IImu Kelautan, Universitas Diponegoro \\ JI. Prof. H. Soedarto S.H, Tembalang,Semarang, Jawa Tengah 50275 Indonesia \\ ${ }^{*}$ Corresponding author, e-mail : anansetya16@gmail.com
}

\begin{abstract}
ABSTRAK: Muara Sungai Banjir Kanal Barat merupakan muara sungai terbesar di Semarang yang alirannya langsung menuju ke laut. Terdapat beberapa aktifitas yang terjadi di sepanjang aliran ini, diantaranya yaitu aktifitas industri dan pemukiman penduduk. Selain itu, adanya pembuangan limbah rumah tangga yang masuk ke dalam badan sungai yang juga berdampak bagi perubahan kualitas perairan serta kehidupan ekosistem di sepanjang aliran sungai tersebut. Fitoplankton merupakan organisme perairan yang keberadaannya dapat dijadikan sebagai indikator kualitas perairan. Penelitian ini bertujuan untuk mengetahui komposisi, kelimpahan, indeks keanekaragaman, indeks keseragaman, dan indeks dominasi fitoplankton di Muara Sungai Banjir Kanal Barat Semarang. Penelitian ini dilakukan pada Oktober-Desember 2019. Metode yang digunakan adalah metode deskriptif eksploratif. Pengambilan sampel dilakukan sebanyak tiga periode dengan interval dua minggu sekali di tiga stasiun. Stasiun 1 merupakan perairan air tawar, stasiun 2 merupakan muara dan stasiun 3 merupakan perairan air laut. Hasil penelitian menunjukkan bahwa terdapat 24 genus fitoplankton dari 3 kelas, yaitu 17 genus dari kelas Bacillariophyceae, 5 genus dari kelas Dinophyceae dan 2 genus dari kelas Cyanophyceae dengan kelimpahan terbesar terdapat pada Stasiun 3 sebesar $67669 \mathrm{sel} / \mathrm{L}$ dan terendah pada Stasiun 1 sebesar $52287 \mathrm{sel} / \mathrm{L}$, indeks keanekaragaman termasuk kategori sedang. Indeks keseragaman termasuk dalam kategori tinggi, indeks dominansi termasuk dalam kategori tidak ada jenis yang mendominasi. Berdasarkan kriteria penilaian menurut Shannon - Wiener bahwa perairan tersebut tergolong ke dalam perairan tercemar sedang.
\end{abstract}

Kata kunci: Fitoplankton; Struktur Komunitas; Muara Sungai; Banjir Kanal Barat

\section{Number and Species Phytoplankton in West Banjir Canal River Estuary Semarang}

ABSTRACT: The Banjir Kanal Barat River Canal is the largest river estuary in Semarang that flows directly to the sea. There are several activities that occur along this flow, including industrial activities and human settlements. In addition, the disposal of household waste that enters the river body also has an impact on changes in water quality and ecosystem life along the river flow. Phytoplankton is aquatic organisms whose existence can be used as indicators of water quality. This study aims to determine the composition, abundance, diversity index, uniformity index, and a dominance index of phytoplankton in the West Banjir Canal River Estuary in Semarang. This research was conducted in October-December 2019. The method used is a descriptive exploratory method. Sampling was conducted in three periods with biweekly intervals at three stations. Station 1 is freshwater waters, station 2 is estuary and station 3 is seawater waters. The results showed that there were 24 genera of phytoplankton from 3 classes, namely 17 genera from the Bacillariophyceae class, 5 genera from the Dinophyceae class and 2 genera from the Cyanophyceae class with the greatest abundance at Station 3 at 67669 cells/L and lowest at Station 1 at $52287 \mathrm{cells} / \mathrm{L}$, the diversity index is in the medium category. Uniformity index is included in the high category, dominance index is included in the category of no species that dominates. Based on the evaluation criteria according to Shannon-Wiener that the waters are classified as medium polluted waters.

Keywords: Phytoplankton; Community Structure; West Banjir Canal Estuary 


\section{PENDAHULUAN}

Fitoplankton ialah organisme air yang berukuran sangat kecil yang mampu berfotosintesis karena memiliki klorofil dan merupakan produsen primer dari rantai makanan di perairan. Fitoplankton berperan penting dalam ekosistem perairan. Fitoplankton mampu membentuk zat organik dari zat anorganik. Proses pasang surut di daerah estuari sangat mempengaruhi kelimpahan fitoplankton, sesuai dengan sifat dasar fitoplankton yang selalu bergerak secara pasif mengikuti arus (Suwandana et al., 2018).

Muara Sungai Banjir Kanal Barat Semarang dikelilingi oleh aktifitas industri dan perumahan penduduk yang tentunya dapat menyumbang pencemaran (pencemaran organik maupun anorganik). Kejadian tersebut akan berdampak terhadap perubahan kualitas perairan yang dapat mempengaruhi produksi perikanan. Salah satu aspek penting dalam mengukur produksi perikanan adalah fitoplankton sebagai sumber makanan.

Perubahan lingkungan yang terjadi pada suatu perairan serta adanya proyek pembangunan yang terdapat di sekitar Sungai Banjir Kanal Barat Semarang nantinya mempengaruhi keberadaan fitoplankton baik langsung atau tidak langsung. Struktur komunitas fitoplankton di perairan bisa digunakan selaku salah satu indikator biologi untuk menetapkan perubahan kondisi perairan tersebut. Mengingat pentingnya peranan fitoplankton dalam jaring-jaring makanan di perairan maka perlu dilakukan suatu kajian struktur komunitas fitoplankton dengan melihat kelimpahan, komposisi, indeks keseragaman, indeks keanekaragaman serta dominansi fitoplankton pada Muara Sungai Banjir Kanal Barat Semarang. Penelitian mengenai Fitoplankton pada berbagai perairan telah dilakukan diantaranya adalah di Cilacap (Wiyarsih et al., 2019), Sumatera Selatan (Munthe \& Aryawati, 2012) dan Bandar Lampung (Meiriyani et al., 2011). Penelitian ini bertujuan dalam mengetahui komposisi, kelimpahan, indeks keanekaragaman, indeks keseragaman, dan indeks dominasi fitoplankton di Muara Sungai Banjir Kanal Barat Semarang.

\section{MATERI DAN METODE}

Materi penelitian berupa fitoplankton yang ditemukan pada sampel air yang didapatkan dari Muara Sungai Banjir Kanal Barat Semarang. Perolehan sampel berdasarkan stasiun-stasiun yang telah ditentukan yaitu perairan air tawar, muara dan perairan air laut. Pengukuran parameter lingkungan terdiri dari suhu, salinitas, $\mathrm{pH}$, oksigen terlarut, nitrat, fosfat, kecerahan serta kecepatan arus.

Penelitian ini menggunakan metode deskriptif, yang bertujuan guna mendalami suatu masalah di waktu tertentu untuk memberikan deskripsi secara sistematis, faktual serta akurat mengenai fakta di lapangan. Penelitian dilakukan mengobservasi langsung ke lokasi guna mengumpulkan data dan informasi terkait suatu gejala saat penelitian dilakukan. Periode I dilakukan tanggal 31 Oktober 2019, Periode II tanggal 14 November 2019 dan Periode III tanggal 28 November 2019 (Mayani et al., 2014). Data dideskripsikan kedalam bentuk tabel dan grafik, sementara analisis data meliputi Kelimpahan, Indeks Keanekaragaman, Indeks Keseragaman serta Indeks Dominasi.

Menurut Nurcahyani et al (2016), data yang telah diperolehkan kemudian diolah untuk mengetahui kelimpahan, dan indeks fitoplankton (keanekaragaman, keseragaman, dominasi). Kelimpahan fitoplankton dapat dihitung dengan menggunakan rumus Welch yaitu dengan mengkalikan jumlah fitoplankton yang teridentifikasi (n) dengan volume uji yang tersaring (b), lalu membaginya dengan hasil kali antara volume uji yang telah disaring dengan volume uji pada Sedgwick rafter (Welch, 1984). Menurut Welch (1992), pertumbuhan fitoplankton dipengaruhi oleh cahaya dari segi kualitas dan kuantitas cahaya, dan cahaya matahari merupakan syarat utama untuk berlangsungnya proses fotosintesis. Kelimpahan fitoplankton merupakan petunjuk dari kesuburan di suatu lingkungan perairan. Kategori perairan subur adalah apabila kelimpahan $>40 \mathrm{x}$ $106 / \mathrm{m}^{3}$, kesuburan sedang apabila kelimpahan $0.1-40 \times 106 / \mathrm{m}^{3}$, dan kurang subur apabila kelimpahan $<0.1 \times 106 / \mathrm{m}^{3}$ (Sofarini, 2016).

Menghitung indeks keanekaragaman fitoplankton digunakan rumus Shannon dan Wiener dimana jika kisaran perhitungan indeks keanekaragaman menunjukkan nilai $\mathrm{H}>3$ berarti keanekaragaman spesies tinggi, $1<\mathrm{H}<3$ berarti keanekaragaman spesies sedang dan $\mathrm{H}<1$ berarti 


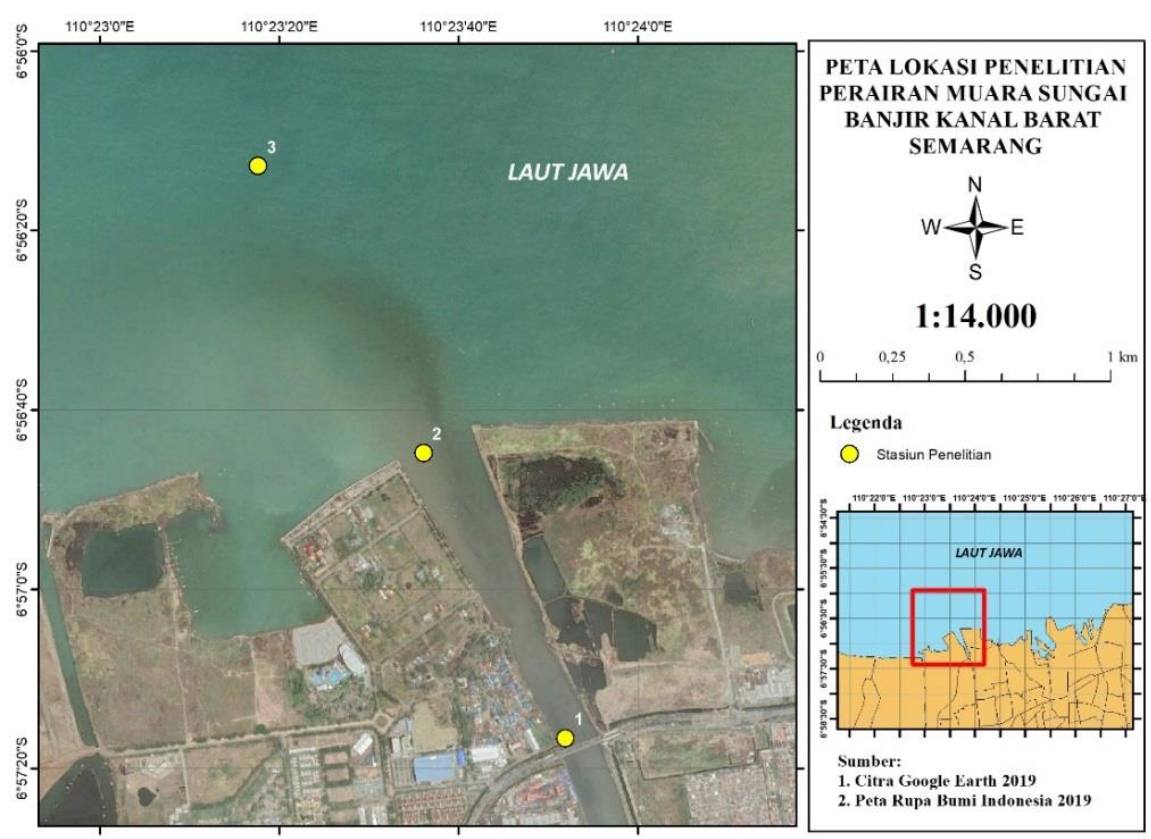

Gambar 1. Peta Lokasi dan Stasiun Penelitian di Perairan Muara Sungai Banjir Kanal Barat

keanekaragaman spesies rendah. Untuk indeks keseragam fitoplankton dapat dihitung menggunakan persamaan Pielou yaitu membagi indeks keanekaragaman $\left(\mathrm{H}^{\prime}\right)$ dengan jumlah jenis (H; maks) (Yulianto et al., 2014). Sedangkan indeks dominasi planton dapat dihitung dengan menggunakan rumus Simpson yaitu dengan cara membagi antara hasil bagi antara jumlah individu $\mathrm{ke}-\mathrm{i}$ (ni) dengan jumlah total individu di dalam komunitas (N). Menurut Odum dalam Adinugroho et al (2014) Nilai indeks dominansi mendekati satu (1) apabila komunitas didominasi oleh jenis atau spesies tertentu dan jika indeks dominansi nol (0) maka tidak ada jenis atau spesies yang mendominasi.

\section{HASIL DAN PEMBAHASAN}

Hasil penelitian di 3 stasiun memperlihatkan adanya perbedaan fitoplankton yang ditemukan. Secara umum terdapat 24 genus tergolong pada 3 kelas diantaranya Bacillariophyceae, Dinophyceae, serta Cyanophyceae. Stasiun 1 ditemukan 16 genus tergolong pada 3 kelas diantaranya Bacillariophyceae (terdapat 13 genus yaitu Rhizosolenia, Pleurosigma, Coscinodiscus, Striatella, Nitzchia, Diatoma, Chaetoceros, Fragillaria, Eucampia, Biddulphia, Pseudo-nitzschia, Triceratium, Navicula), Dinophyceae (terdapat 2 genus yaitu Peridinium dan Prorocentrum) serta Cyanophyceae (terdapat 1 genus yaitu Oscillatoria)

Stasiun 2 ditemukan 18 genus tergolong pada 3 kelas yaitu Bacillariophyceae (terdapat 13 genus yaitu Rhizosolenia, Pleurosigma, Coscinodiscus, Striatella, Nitzchia, Diatoma, Chaetoceros, Thalassiotrix, Flagillaria, Eucampia, Biddulphia, Thalassionema, Stephanopyxis, Bacteriastrum), Dinophyceae (terdapat 2 genus yaitu Ceratium dan Prorocentrum) serta Cyanophyceae (terdapat 2 genus yaitu Spirulina dan Oscillatoria).

Stasiun 3 ditemukan 19 genus tergolong pada 3 kelas diantaranya Bacillariophyceae (terdapat 13 genus yaitu Rhizosolenia, Pleurosigma, Coscinodiscus, Striatella, Nitzchia, Diatoma, Chaetoceros, Thalassiotrix, Fragillaria, Eucampia, Biddulphia, Bacteriastrum, Stephanopyxis), Dinophyceae (terdapat 4 genus yaitu Dinophysis, Ceratium, Protoperidinium dan Prorocentrum), Cyanophyceae (terdapat 2 genus yaitu Spirulina dan Oscillatoria). Perbandingan komposisi fitoplankton Perairan Muara Sungai Banjir Kanal Barat Semarang secara lengkap ditampilkan pada Gambar 2. 


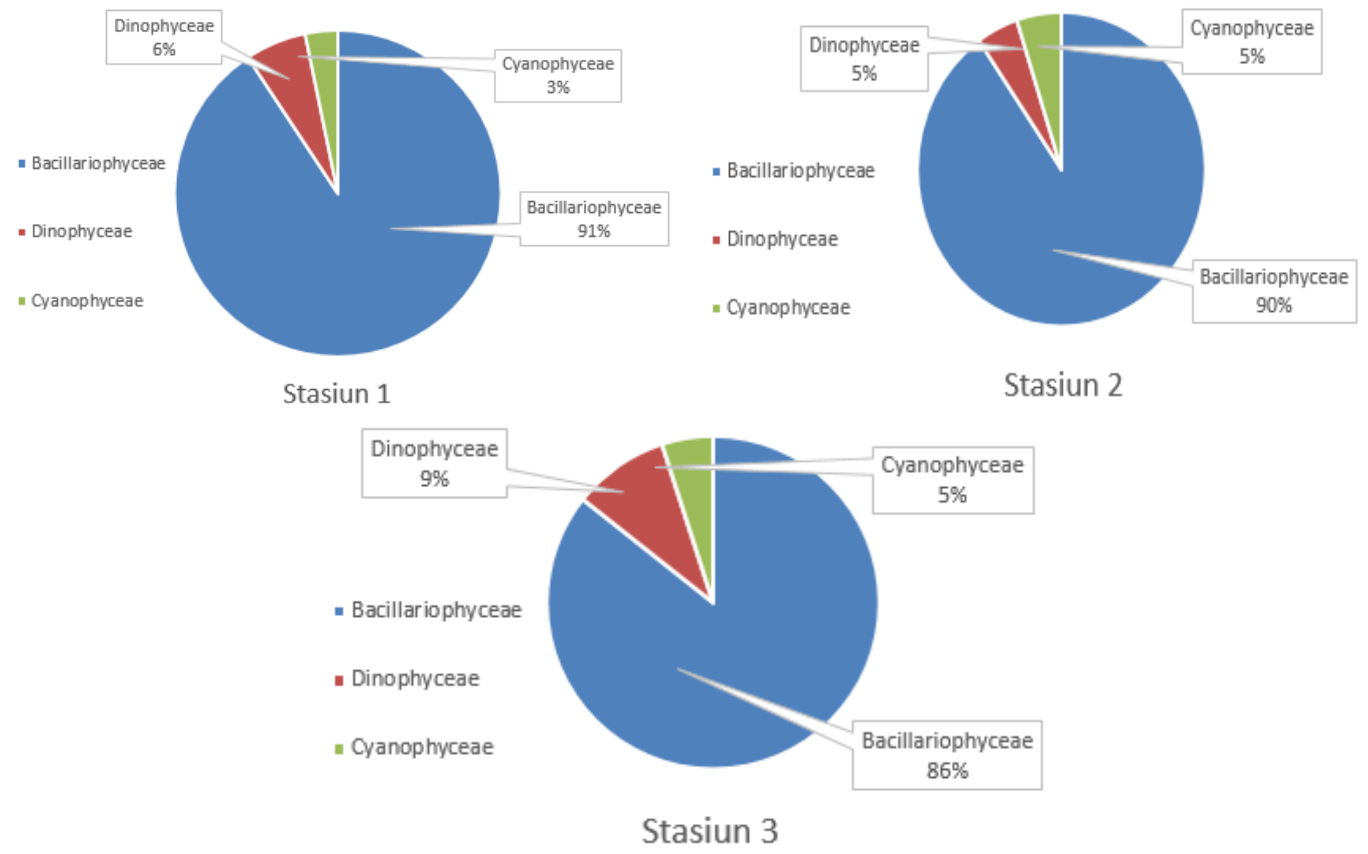

Gambar 2. Diagram Komposisi Fitoplankton Perairan Muara Sungai Banjir Kanal Barat Semarang

Ketiga periode menunjukkan hasil yang berbeda, dimana Periode I kelimpahan tertinggi ditemukan di Stasiun 3 berjumlah 26388 sel/L, sedangkan kelimpahan terendah ditemukan di Stasiun 1 berjumlah $23562 \mathrm{sel} / \mathrm{L}$. Periode II dengan kelimpahan tertinggi terdapat di Stasiun 3 berjumlah 19757 sel/L sedangkan kelimpahan terendah ditemukan di Stasiun 1 sejumlah 13778 sel/L. Periode III dengan kelimpahan tertinggi ditemukan di Stasiun 3 sejumlah 21524 sel/L, sedangkan kelimpahan terendah ditemukan di Stasiun 1 sejumlah $14947 \mathrm{sel} / \mathrm{L}$. Jadi, kelimpahan fitoplankton tertinggi secara keseluruhan ada pada Stasiun 3 serta kelimpahan fitoplankton terendah secara keseluruhan terdapat pada Stasiun 1. Perbandingan jumlah kelimpahan rata-rata fitoplankton berdasarkan periode yang berbeda Perairan Muara Sungai Banjir Kanal Barat Semarang (Tabel 1)

Indeks keanekaragaman $\left(H^{\prime}\right)$ fitoplankton di Muara Sungai di kisaran 1,70 -2,56, tergolong kategori sedang. Nilai keanekaragaman tertinggi ada di Stasiun 3 Periode II dengan nilai 2,56 sedangkan nilai keanekaragaman paling rendah ada di Stasiun 1 Periode I dengan nilai 1,70. Indeks keanekaragaman fitoplankton Perairan Muara Sungai Banjir Kanal Barat Semarang secara lengkap tersaji dalam Gambar 3.

Indeks Keseragaman (E) fitoplankton di Muara Sungai Banjir Kanal Barat Semarang secara keseluruhan di kisaran 0,61 - 0,87, termasuk pada kategori tinggi. Nilai keseragaman paling tinggi ada di Stasiun 3 Periode II dengan nilai 0,87 sementara nilai keseragaman terendah ada di Stasiun 1 Periode I dengan nilai 0,61. Indeks keseragaman fitoplankton pada Perairan muara sungai secara lengkap tersaji dalam Gambar 4.

Indeks dominansi fitoplankton muara sungai pada kisaran 0,11-0,28 dimana nilai tersebut termasuk dalam kategori tidak mendominasi. Nilai dominasi tertinggi ada di Stasiun 1 Periode I dengan nilai 0,28 sedangkan nilai dominasi terendah berada di Stasiun 3 Periode II dengan nilai 0,11. Indeks dominasi fitoplankton perairan muara sungai secara lengkap tersaji dalam Gambar 5.

Tabel 1. Kelimpahan Fitoplankton Perairan Muara Sungai Banjir Kanal Barat Semarang (sel/L)

\begin{tabular}{ccccc}
\hline Kelimpahan & Periode I & Periode II & Periode III & Total \\
\hline Stasiun 1 & 23562 & 13778 & 14947 & 52287 \\
Stasiun 2 & 24042 & 15708 & 18779 & 58529 \\
Stasiun 3 & 26388 & 19757 & 21524 & 67669 \\
Total & 73992 & 49243 & 55250 & 178485 \\
\hline
\end{tabular}




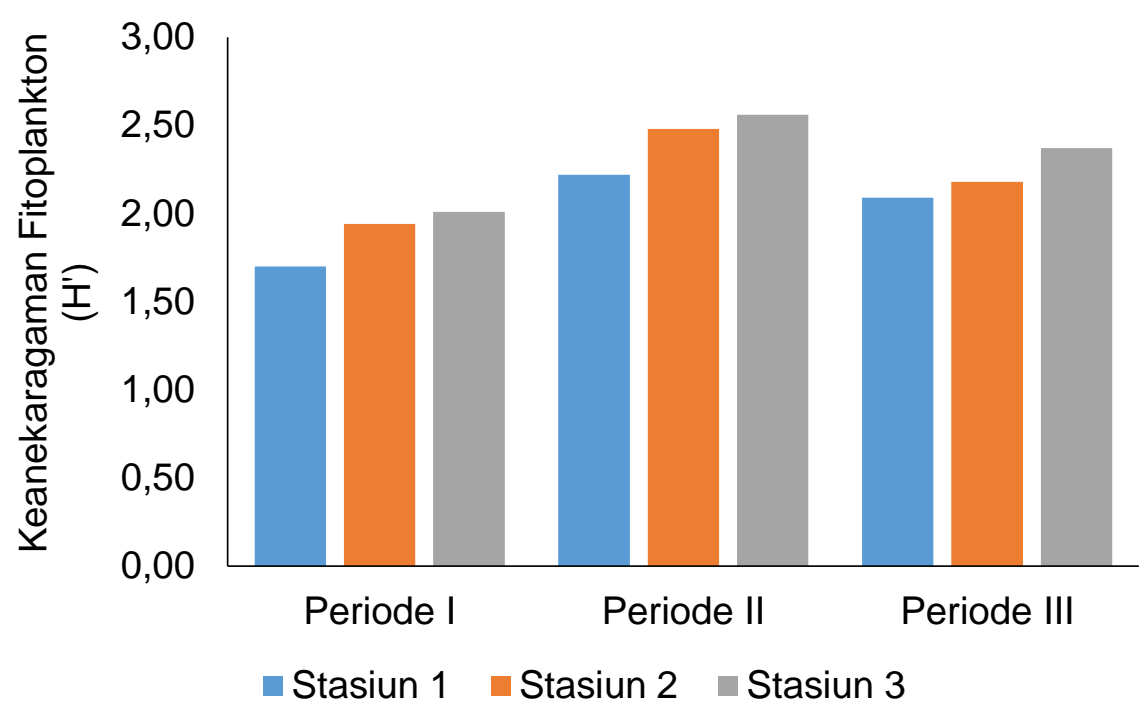

Gambar 3. Indeks Keanekaragaman Fitoplankton di Muara Sungai Banjir Kanal Barat Semarang

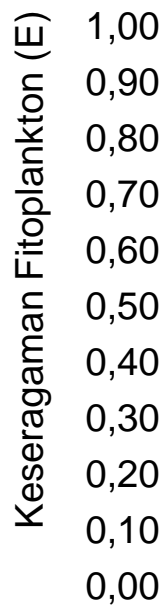

\section{Periode I \\ Periode II \\ Periode III}

- Stasiun 1 Stasiun 2 Stasiun 3

Gambar 4. Indeks Keseragaman Fitoplankton di Perairan Muara Sungai Banjir Kanal Barat Semarang

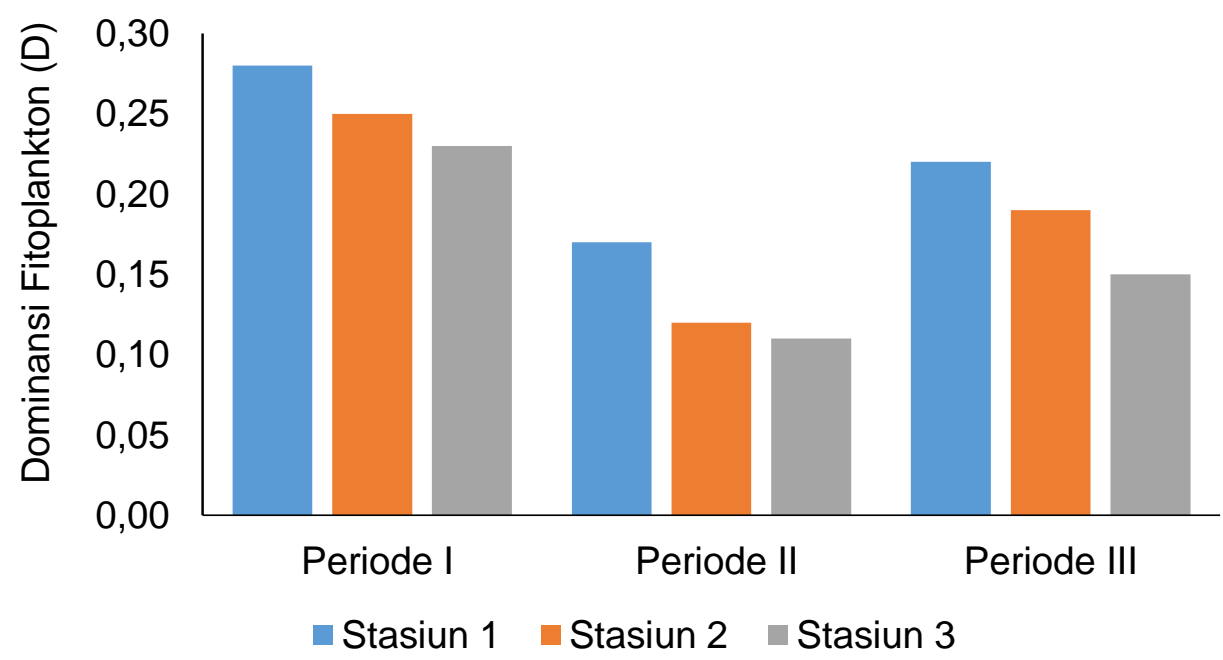

Gambar 5. Indeks Dominansi Fitoplankton di Perairan Muara Sungai Banjir Kanal Barat Semarang 
Pengukuran parameter perairan pada Perairan Muara Sungai Banjir Kanal Barat Semarang meliputi suhu, kecerahan, arus, salinitas, pH, DO, Nitrat serta Fosfat. Pengukuran parameter tersebut dilaksanakan pada setiap stasiun untuk menggambarkan kondisi lingkungan perairan daerah penelitian tersebut, lalu pada pengukuran nitrat dan fosfat diujikan di laboratorium. Hasil pengukuran perairan adalah sebagai berikut.

Tabel 2. Pengukuran Parameter Perairan Bulan Oktober - November 2019 pada Perairan Muara Sungai Banjir Kanal Barat Semarang

\begin{tabular}{|c|c|c|c|c|}
\hline \multirow{2}{*}{ Parameter } & \multirow{2}{*}{ Satuan } & \multicolumn{3}{|c|}{ Stasiun } \\
\hline & & 1 & 2 & 3 \\
\hline \multicolumn{5}{|l|}{ Periode I } \\
\hline Suhu & ${ }^{\circ} \mathrm{C}$ & $30,5-32$ & $30,8-32$ & $31,3-32$ \\
\hline Kecerahan & $\mathrm{cm}$ & $18-20$ & $32-39$ & $88-93$ \\
\hline Arus & $\mathrm{m} / \mathrm{s}$ & $0-0,2$ & $0,2-0,4$ & $0,3-0,5$ \\
\hline Salinitas & $\%$ & 0 & $24-27$ & $31-35$ \\
\hline $\mathrm{pH}$ & & $6-7$ & $6-7$ & $7-8$ \\
\hline DO & $\mathrm{mg} / \mathrm{l}$ & $5,71-5,83$ & $5,62-5,70$ & $5,90-5,98$ \\
\hline Nitrat & $\mathrm{mg} / \mathrm{l}$ & 0,5532 & 0,4809 & 0,5277 \\
\hline Fosfat & $\mathrm{mg} / \mathrm{l}$ & 1,6572 & 0,8421 & 0,1107 \\
\hline \multicolumn{5}{|l|}{ Periode II } \\
\hline Suhu & ${ }^{\circ} \mathrm{C}$ & $28-30$ & $29-30$ & $29,8-30,7$ \\
\hline Kecerahan & $\mathrm{cm}$ & $14-17$ & $25-28$ & $85-89$ \\
\hline Arus & $\mathrm{m} / \mathrm{s}$ & $0-0,2$ & $0,1-0,3$ & $0,2-0,4$ \\
\hline Salinitas & $\%$ & 0 & $24-28$ & $32-35$ \\
\hline $\mathrm{pH}$ & & $6-7$ & $6-7$ & $6-8$ \\
\hline DO & $\mathrm{mg} / \mathrm{l}$ & $5,41-5,49$ & $5,62-5,67$ & $5,86-5,90$ \\
\hline Nitrat & $\mathrm{mg} / \mathrm{l}$ & 0,5865 & 0,4937 & 0,5612 \\
\hline Fosfat & $\mathrm{mg} / \mathrm{l}$ & 0,5788 & 0,0052 & 0,4067 \\
\hline \multicolumn{5}{|l|}{ Periode III } \\
\hline Suhu & ${ }^{\circ} \mathrm{C}$ & $30,2-30,5$ & $30,8-31,2$ & $31,4-31,7$ \\
\hline Kecerahan & $\mathrm{cm}$ & $17-19$ & $27-29$ & $89-91$ \\
\hline Arus & $\mathrm{m} / \mathrm{s}$ & $0-0,2$ & $0,2-0,4$ & $0,2-0,5$ \\
\hline Salinitas & $\%$ & 0 & $28-29$ & $31-35$ \\
\hline $\mathrm{pH}$ & & $6-7$ & $6-7$ & $7-8$ \\
\hline DO & $\mathrm{mg} / \mathrm{l}$ & $5,59-5,62$ & $5,53-5,56$ & $5,81-5,84$ \\
\hline Nitrat & $\mathrm{mg} / \mathrm{l}$ & 0,6567 & 0,3176 & 0,3734 \\
\hline Fosfat & $\mathrm{mg} / \mathrm{l}$ & 0,3550 & 0,0671 & 0,1313 \\
\hline
\end{tabular}

Hasil penelitian fitoplankton pada Perairan Muara Sungai Banjir Kanal Barat Semarang menemukan 24 genus tergolong pada 3 kelas. Kelas Bacillariophyceae ditemukan sebanyak 17 genus, Dinophyceae ada 5 genus, dan Cyanophyceae terdapat 2 genus. Komposisi fitoplankton yang sering dijumpai pada penelitian ini ialah kelas Bacillariophyceae. Hal ini diduga Bacillariophyceae memiliki kemampuan toleransi terhadap lingkungan yang lebih baik dibanding kelas lainnya.

Menurut Zulfiandi et al (2014) Bacillariophyceae merupakan kelas yang paling banyak ditemukan dalam perairan. Bacillariophyceae adalah salah satu kelompok fitoplankton yang secara kualitatif dan kuantitatif banyak terdapat di berbagai perairan. Ini dikarenakan kemampuan fitoplankton kelas Bacillariophyceae mudah beradaptasi dan tahan terhadap kondisi lingkungan yang ekstrem. Jumlah genus yang cukup banyak dari Bacillariophyceae mempunyai sebaran yang luas serta mampu hidup di berbagai habitat sehingga keberadaannya sering dijumpai di perairan laut terbuka, pantai maupun estuaria.

Hasil menunjukkan bahwa suhu rata - rata pada Perairan Muara Sungai Banjir Kanal Barat Semarang pada kisaran $28-32{ }^{\circ} \mathrm{C}$. Suhu tersebut masih bisa diterima fitoplankton untuk kelangsungan hidup serta pertumbuhan. Ini sesuai dengan pernyataan Hainuna et al. (2015) bahwa 
rerata suhu air optimum pada kisaran $24-32^{\circ} \mathrm{C}$ dimana plankton dapat tumbuh dan berkembang dengan baik.

Menurut KEPMEN LH (2004) kondisi derajat keasaman optimal untuk kehidupan fitoplankton adalah 6 - 8,5. Kondisi fotosintesis akan optimal ketika pH berada pada keadaan normal (Lantang dan Chalvin, 2015). Berdasarkan penelitian nilai pH rata rata di perairan muara sungai pada kisaran $6-8$. Jadi, kondisi $\mathrm{pH}$ masih memadai bagi kehidupan fitoplankton.

Komposisi jenis kelas Dinophyceae ditemukan lebih sedikit daripada kelas Bacillariophyceae pada penelitian ini. Menurut Tasak et al (2015) pertumbuhan Dinophyceae sangat dipengaruhi oleh kekuatan cahaya yang masuk ke perairan dan keseimbangan rasio antara nitrat dan fosfat.

Kelas Cyanophyceae hanya ditemukan 2 genus dan paling sedikit diantara kelas lainnya. Menurut Munthe et al (2012) kelas Cyanophyceae sangat jarang ditemukan sehingga mengakibatkan nilai kelimpahan rerata kelas tersebut lebih sedikit dibanding kelas Bacillariophyceae atau kelas lainnya.

Genus dari kelas Bacillariophyceae yang mempunyai jumlah paling banyak di setiap stasiun adalah Rhizosolenia. Menurut Adinugroho (2014) Rhizosolenia merupakan makanan alami untuk ikan - ikan yang hidup diperairan khususnya di laut. Selain itu, pada setiap stasiun juga ditemukan genus Pleurosigma dan Coscinodiscus. Genus ini banyak ditemukan diperairan lantaran daya adaptasi salintias yang lebih baik dibanding kelas lainnya, serta dapat bertahan di kondisi lingkungan yang tercemar. Terdapat genus yang hanya ditemukan pada Stasiun 1 yaitu genus Navicula. Hal ini karena Stasiun 1 memiliki kandungan nitrat yang di kisaran 0,5532 - 0,6567 $\mathrm{mg} / \mathrm{l}$ serta fosfat pada kisaran 0,3550 - 1,6572 mg/l yang cukup baik bagi genus Navicula dalam mendukung pertumbuhannya, Navicula dapat bertahan di perairan yang memiliki sedikit cahaya dan rendah salinitasnya. Stasiun 1 yang merupakan perairan air tawar bersalinitas rendah tapi memiliki kandungan nitrat serta fosfat yang cukup tinggi. Genus Ceratium dan Prorocentrum merupakan fitoplankton kelas Dinophyceae yang paling banyak ditemukan. Selain itu, genus dari kelas Dinophyceae yang ditemukan adalah genus Dinophysis. Genus Dinophysis ditemukan di Stasiun 3 yang adalah perairan laut.ra Sedangkan fitoplankton kelas Cyanophyceae yang umum ditemukan di penelitian ini adalah genus Oscillatoria. Genus Oscillatoria dapat berkembang di kadar fosfat optimal untuk pertumbuhan fitoplankton ialah $0,09-1,80 \mathrm{mg} / \mathrm{l}$. Hal ini sesuai dengan hasil pengujian fosfat yang pada kisaran $0,0052-1,6572 \mathrm{mg} / \mathrm{l}$ (Wiyarsih et al., 2019).

Berdasarkan hasil penelitian, kelas fitoplankton yang tidak ditemukan adalah kelas dari Chlorophyceae. Chlorophyceae tidak ditemukan pada Stasiun 1 yang merupakan perairan tawar kemungkinan dikarenakan Stasiun 1 masih berdekatan dengan Stasiun 2 yang merupakan muara sungai yang tergolong dalam perairan payau sehingga terkadang masih ada percampuran antara air tawar dengan air laut. Menurut Samudra et al. (2013) kelas Chlorophyceae jarang ditemukan karena memiliki tingkat pertumbuhan yang lambat. Munthe et al. (2012) menambahkan bahwa arus disebabkan oleh kegiatan pasang surut, dimana pada saat pasang daerah muara sungai mendapatkan pasokan air laut sedangkan pada saat surut perairan muara banyak mendapatkan pasokan air tawar. Pada saat pengambilan sampel dilakukan yang terjadi adalah pada saat pasang, sehingga jenis fitoplankton air laut banyak yang ikut terbawa oleh arus yang menyebabkan kelas Chlorophyceae yang merupakan fitoplankon air tawar tidak ditemukan pada penelitian ini.

Berdasarkan hasil penelitian, kelimpahan fitoplankton di kisaran 13778 - 26388 sel/L. Kelimpahan fitoplankton paling tinggi terdapat pada Periode I yaitu sebanyak 73992 sel/L dan paling rendah terdapat pada Periode II yaitu sebanyak $49243 \mathrm{sel} / \mathrm{L}$. Kondisi cuaca saat pengambilan sampel pada Periode I yaitu cerah sehingga cahaya matahari dapat masuk ke perairan dan fitoplankton bisa memanfaatkannya guna fotosintesis sedangkan saat pengambilan sampel pada Periode II cuacanya mendung sehingga cahaya matahari terhalang oleh awan dan kekuatan cahaya yang masuk ke perairan akan menurun. Hal ini yang menyebabkan tingginya kelimpahan pada Periode I dan rendahnya kelimpahan pada Periode II.

Menurut Zulfiandi et al (2014) bahwa kelimpahan fitoplankton dipengaruhi oleh cahaya matahari yang sangat diperlukan oleh fitoplankton untuk melakukan fotosintesis, sehingga fitoplankton akan naik ke permukaan dan kelimpahannya sangat tinggi pada saat surut.

Kelimpahan fitoplankton paling tinggi pada penelitian ini terdapat pada stasiun 3. Dimana stasiun 3 merupakan perairan air laut yang merupakan tempat yang cocok untuk tumbuh dan 
berkembang bagi fitoplankton. Biasanya fitoplankton tumbuh di kondisi salinitas air laut normal pada salinitas $30-40 \%$ (Nova dan Misbah, 2012). Hal ini sesuai dengan salinitas pada stasiun 3 yang pada kisaran $31-35 \%$ sesuai pada tabel 4 .

Unsur hara seperti nitrat dan fosfat juga berpengaruh terhadap kelimpahan dari fitoplankton. Kelimpahan fitoplankton sangat dipengaruhi oleh kekuatan cahaya yang masuk ke perairan dan keseimbangan rasio antara nitrat dan fosfat (Tasak et al., 2015). Menurut Mustofa (2015) konsentrasi nitrat yang pada kisaran 0,09 - 3,5 mg/l sangat optimal untuk pertumbuhan fitoplankton. Fajar et al (2016) menambahkan bahwa untuk pertumbuhan fitoplankton yang baik dibutuhkan kandungan fosfat yang pada kisaran $0,08-1,80 \mathrm{mg} / \mathrm{l}$. Hal ini sesuai dengan hasil pengujian parameter nitrat dan fosfat di laboratorium berdasarkan penelitian ini pada kisaran 0,3176 - 0,6567 mg/l, sedangkan pengujian parameter fosfat paling tinggi sebesar 1,6572 mg/l.

Menurut Fajar et al., (2016) kecerahan juga berpengaruh terhadap kehidupan fitoplankton. Kecerahan dipengaruhi oleh kekeruhan air akibat tingginya kandungan bahan organik serta anorganik tersuspensi. Semakin rendah nilai kecerahan yang diperoleh semakin sulit sinar matahari akan masuk ke dalam perairan, begitu pula sebaliknya semakin tinggi nilai kecerahan semakin mudah sinar matahari akan masuk ke dalam perairan hingga dapat mempengaruhi kehidupan fitoplankton dalam perairan tersebut. Kecerahan juga berkaitan dengan proses fotosintesis yang terjadi di perairan secara alami. Nilai kecerahan paling rendah terdapat pada stasiun 1 yang pada kisaran $14-20 \mathrm{~cm}$. Dimana fitoplankton akan sulit berfotosintesis pada perairan yang memiliki nilai kecerahan rendah dibanding dengan stasiun 3 yang memiliki nilai kecerahan paling tinggi sebesar $93 \mathrm{~cm}$.

Nilai $\mathrm{pH}$ pada perairan muara sungai Banjir Kanal Barat Semarang secara keseluruhan memiliki kisaran antara 6 - 8. Stasiun 1 maupun stasiun 2 mendapatkan nilai pH berkisar antara 6 - 7. Stasiun 3 memiliki nilai pH kisaran 6 - 8 . Nilai pH pada penelitian ini masih sesuai dengan Kep.51/MENKLH/2004 tentang baku mutu air laut untuk biota laut bahwa kadar $\mathrm{pH}$ perairan yang baik untuk pertumbuhan fitoplankton di kisaran 6 - 8,5.

Menurut Odum (1993) Sifat komunitas memperlihatkan tingkat keanekaragaman jenis yang ada pada suatu komunitas tersebut. Keanekaragaman tidak hanya tergantung pada jumlah jenis atau genus tetapi juga tergantung dari kelimpahan individu dalam tiap jenis. Indeks keanekaragaman fitoplankton di Muara Sungai Banjir Kanal Barat Semarang secara keseluruhan bervariasi antara 1,70 - 2,56 dengan kategori keanekaragaman sedang. Menurut waktu pengambilan sampel, indeks keanekaragaman rerata paling tinggi ada pada Stasiun 3 Periode II dengan indeks sebesar 2,56 serta indeks keanekaragaman rerata paling rendah ada ditemukan di Stasiun 1 Periode I dengan nilai 1,70.

Indeks Keanekaragaman terendah ditemukan di Periode I dan termasuk kategori keanekaragaman sedang, dikarenakan di Periode I terdapat spesies yang jumlah individunya lebih banyak sehingga kelimpahan spesies tersebut tinggi. Jika terdapat jenis atau spesies yang kelimpahan individunya tinggi maka indeks keanekaragamannya akan lebih kecil. Prawiradilaga et al (2003) menambahkan bahwa kriteria penilaian berdasarkan indeks keanekaragaman Shannon Wiener jika keanekaragaman sedang tergolong dalam perairan tercemar sedang.

Nilai Indeks Keseragaman (E) menggambarkan berapa besar kesamaan penyebaran jumlah individu masing-masing jenis. Indeks keseragaman memiliki hubungan terbalik dengan nilai indeks dominansi yaitu jika nilai indeks keseragaman tinggi maka indeks dominansi rendah begitu pula sebaliknya. Secara keseluruhan indeks keseragaman dari penelitian ini diperolehkan hasil dengan kisaran nilai 0,61 - 0,87 dimana termasuk dalam kategori tinggi. Indeks keseragaman fitoplankton paling tinggi terdapat pada stasiun rerata paling tinggi ada di Stasiun 3 Periode II dengan nilai indeks 0,87 termasuk dalam kategori keseragaman tinggi (e > 0,6 : Kategori tinggi) (Krebs, 1985). Indeks keseragaman paling rendah ditemukan di Stasiun 1 Periode I dengan nilai 0,61 dan termasuk dalam kategori tinggi (e > 0,6 : Kategori tinggi) (Krebs, 1985). Hal ini karena karena tidak ada spesies yang mendominasi spesies lainnya.

Menurut Fajrina et al. (2013) Nilai indeks keseragaman mendekati 1 dapat diartikan keseragaman antar spesies merata atau jumlah individu pada masing-masing spesies hampir sama. Nilai dari Indeks Keseragaman fitoplankton ini menunjukkan kemampuan toleransi dari setiap jenis terhadap kualitas lingkungan, hanya individu dengan kemampuan toleransi cukup tinggi dari setiap stasiun yang dapat ditemukan. Menurut Nurul et al. (2011) Indeks keseragaman 
yang mendekati nol cenderung menunjukkan komunitas yang tidak stabil, sedangkan jika mendekati satu (1) maka komunitas dalam keadaan stabil, jumlah individu antar jenis sama. Perbedaan indeks keseragaman di stasiun 1, 2, dan 3 dipengaruhi oleh jumlah spesies, jumlah individu jenis/spesies serta jumlah individu semua jenis (jumlah total individu) yang ditemukan pada setiap periode. Perbedaan jumlah spesies dan jumlah individu jenis atau spesies dipengaruhi oleh perubahan sifat fisika-kimia pada Perairan Muara Sungai Banjir Kanal Barat Semarang.

Indeks dominansi fitoplankton pada Muara Sungai Banjir Kanal Barat Semarang pada kisaran $0,11-0,28$. Indeks dominasi rerata tertinggi ada di Stasiun 1 Periode I dengan nilai 0,28 dimana termasuk dalam kategori tidak mendominasi. Indeks dominasi fitoplankton rerata terendah terdapat di Stasiun 3 Periode II dengan nilai 0,11 termasuk dalam kategori tidak mendominasi $(0<$ $\mathrm{D}<0,5$ = tidak ada dominansi) (Odum, 1993).

Nilai Indeks Dominasi (D) tersebut memiliki arti bahwa pada pengamatan struktur komunitas fitoplankton tidak ada genus yang mendominasi spesies lainnya secara ekstrim. Parameter fisikakimia air berada pada kisaran yang sesuai sehingga tidak terjadi kompetisi, semua genus memiliki peluang yang sama untuk dapat hidup dan berkembang biak. Hal ini menunjukkan bahwa kondisi struktur komunitas dalam keadaan stabil, kondisi lingkungan yang cukup prima dan tidak terjadi tekanan ekologis terhadap biota (Yuliana, 2014).

\section{KESIMPULAN}

Hasil penelitian menyimpulkan fitoplankton yang ditemukan pada penelitian di Perairan Muara Sungai Banjir Kanal Barat Semarang ini sebanyak 24 genus dari 3 kelas, yaitu Bacillariophyceae, Dinophyceae, dan Cyanophyceae. Kelimpahan fitoplankton di Perairan Muara Sungai Banjir Kanal Barat Semarang terbesar terdapat pada Stasiun 3 yang merupakan perairan laut sebesar $67669 \mathrm{sel} / \mathrm{L}$ dan kelimpahan terendah terdapat pada Stasiun 1 yang merupakan perairan tawar sebesar $52287 \mathrm{sel} / \mathrm{L}$. Indeks keanekaragaman yang didapatkan masuk pada kategori sedang, Indeks keseragaman yang termasuk pada kategori tinggi sedangkan indeks dominasi yang berarti tidak ada dominasi dari genus tertentu.

\section{DAFTAR PUSTAKA}

Adinugroho, M., Subiyanto, \& Haeruddin. 2014. Komposisi dan Distribusi Plankton di Perairan Teluk Semarang. Saintifika, 16(2):39-48.

Afif, A., Widianingsih \& Retno, H. 2014. Komposisi dan Kelimpahan Plankton di Perairan Pulau Gusung Kepulauan Selayar Sulawesi Selatan. Journal of Marine Research 3(3):324-331

Aprianti, N.S., Bambang, S. \& Mustofa, M. Kajian Tentang Fitoplankton yang Berpotensi Sebagai HABs (Harmful Algal Blooms) di Muara Sungai Plumbon, Semarang. Management of Aquatic Resources Journal, 4(3):132-138

Fajar, M.G.N., Rudiyanti S. \& A'in, C. 2016. Pengaruh Unsur Hara Terhadap Kelimpahan Fitoplankton Sebagai Bioindikator Pencemaran di Sungai Gambir Tembalang Kota Semarang. Diponegoro Journal of Maquares, 5(1):32-37.

Fajrina Hilyati, Hadi Endrawati dan Muhammad Zainuri. 2013. Struktur Komunitas Fitoplankton di Perairan Morosari Kecamatan Sayung Kabupaten Demak. Journal of Marine Research, 2(1): 71-79.

Hainuna, E.D.N., Ricky, G, \& Ludji, M.R.K. Pemanfaatan Fitoplankton Sebagai Bioindikator Berbagai Jenis Polutan di Perairan Intertidal Kota Kupang. Jurnal IImu Lingkungan. 13(2):7285.

Kementrian Lingkungan Hidup. 2004 Kepmen LH no 51 tahun 2004 tentang Baku Mutu Air Laut. Menteri Negara Lingkungan Hidup. Jakarta.

Lantang, B., \& Chalvin, S.P. 2015. Identifikasi Jenis dan Pengaruh Faktor Oseanografi Terhadap Fitoplankton di Perairan Pantai Payum - Pantai Lampu Satu Kabupaten Merauke. Agrikan: Jurnal Agribisnis Perikanan, 8(2):13-19.

Mayani, P.S., Widianingsih, W. \& Endrawati, H. 2014. Kajian Struktur Komunitas Fitoplankton di Perairan Pantai Desa Tapak Kecamatan Tugu Kota Semarang. Journal of Marine Research, 3(4):535-543. DOI: 10.14710/jmr.v3i4.11412 
Meiriyani, F., Ulqodry, T.Z. \& Putri, W.A.E. 2011. Komposisi dan Sebaran Fitoplankton di Perairan Muara Sungai Way Belau, Bandar Lampung. Maspari Journal, 03:69-77.

Munthe, Y.V., Aryawati, R. \& Isnaini, I. 2012. Struktur Komunitas dan Sebaran Fitoplankton di Perairan Sungsang Sumatera Selatan. Maspari Journal, 4(1): 122-130.

Mustofa, A. 2015. Kandungan Nitrat dan Pospat Sebagai Faktor Tingkat Kesuburan Perairan Pantai. Jurnal Disprotek. 6(1):13-19. DOI: 10.34001/jdpt.v6i1.193

Nova, S.M.K \& Misbah, N. 2012. Analisis Pengaruh Salinitas dan Suhu Air Laut Terhadap Laju Korosi Baja A36 pada Pengelasan SMAW. Jurnal Teknik ITS, 1:75-77.

Nurcahyani, E.A., Hutabarat, S., \& Sulardiono, B. 2016. Distribusi Dan Kelimpahan Fitoplankton Yang Berpotensi Menyebabkan Habs (Harmful Algal Blooms) Di Muarasungai Banjir Kanal Timur, Semarang. Management of Aquatic Resources Journal, 5(4), 275-284.

Nurul, F., Surbakti, H., Riris, A. 2011. Pola Sebaran Fitoplankton serta Klorofil-a pada Bulan November di Perairan Tambelan, Laut Natuna. Maspari Journal, 3: 1-8.

Samudra, S.R, Tri, R.S \& Munifatul, I. 2013. Komposisi, Kemelimpahan dan Keanekaragaman Fitoplankton Danau Rawa Pening Kabupaten Semarang. Bioma. 15(1):6-13.

Sofarini, D. 2016. Keberadaan dan Kelimpahan Fitoplankton Sebagai Salah Satu Indikator Kesuburan Lingkungan Perairan di Waduk Riam Kanan. EnviroScienteae. 8(1):30-34.

Suwandana, A., Pujiono, W. \& Siti, R. 2018. Analisis Perbandingan Fitoplankton dan Zooplankton Serta TSI (Trophic Saprobic Index) pada Perairan Tambak di Kampung Tambak Lorok Semarang. Diponegoro Journal of Maquares, 7(3):237-245.

Tasak, A., Kawaroe, M. \& Pratono, T. 2015. Keterkaitan Kekuatan Cahaya dan Kelimpahan Dinoflagellate di Pulau Samalona, Makassar. Jurnal IImu Kelautan, 20(2):113-120. DOI: 10.14710/ik.ijms.20.2.113-120.

Welch, P.S. 1984. Limnological Methods. Mc Grow-Hill Book Company Inc. USA.

Welch. 1992. Limnology. Mc Graw Hill. Company New York. USA.

Wiyarsih, B., Endrawati, H. \& Sedjati, S.. 2019. Komposisi dan Kelimpahan Fitoplankton di Laguna Segara Anakan, Cilacap. Buletin Oseanografi Marina, 8(1):1-8. DOI: 10.14710/buloma. v8i1.21974.

Yuliana. 2014. Hubungan Antara Kelimpahan Kista Dinophyceae dengan Parameter Fisika-Kimia Perairan di Teluk Jakarta. Jurnal Perikanan, 16(2):72-78.

Yulianto, D., Muskananfola, M.R. \& Purnomo, P.W. 2014. Tingkat Produktivitas Primer dan Kelimpahan Fitoplankton Berdasarkan Waktu yang Berbeda di Perairan Pulau Panjang, Jepara. Diponegoro Journal of Maquares, 3(4):195-200.

Zulfiandi, Zainuri, M. \& Widowati, I. 2014. Kajian Distribusi/Sebaran Fitoplankton dan Zooplankton di Perairan dan Estuaria Banjir Kanal Barat Kota Semarang Jawa Tengah. Dalam: Prosiding Seminar Nasional Kelautan IX di Universitas Hang Tuah Surabaya Tanggal 24 April 2014. Surabaya, hIm 24-31. 